\title{
MICHAŁ KOZŁOWSKI
}

ORCID: 0000-0002-9372-9292

\section{HENRYK SAMSONOWICZ \\ (1930-2021)}

DOI: $10.15290 /$ sp.2021.29.20

Henryk Samsonowicz urodził się w Warszawie w 1930 r. ${ }^{1}$ Jego ojciec prof. Jan Samsonowicz (1888-1959) ${ }^{2}$ był geologiem i paleontologiem, wykładowcą Uniwersytetu Jana Kazimierza we Lwowie i Uniwersytetu Warszawskiego, członkiem Polskiej Akademii Nauk. Matka uczonego, Henryka Korwin-Krukowska (1892-1987) uczyła geografii w Liceum im. Juliusza Słowackiego w Warszawie ${ }^{3}$. Starszym bratem Henryka był Andrzej Samsonowicz (1922-1944), żołnierz batalionu „Zośka”, poległy w Powstaniu Warszawskim ${ }^{4}$. Henryk po wojnie uczęszczał do Liceum im. Juliusza Słowackiego w Warszawie, gdzie jednym z jego kolegów był Janusz Tazbir. Po maturze rozpoczął studia w Instytucie Historii Uniwersytetu Warszawskiego. Razem z nim na roku studiowała Lucyna Berman ${ }^{5}$, dziennikarz i działacz Pax-u Wojciech Kętrzyński a także grono późniejszych znanych historyków:

1 Podstawowe dane biograficzne: A.G. Kister, Henryk Bohdan Samsonowicz, [w:] Encyklopedia Solidarności, https://archive.is/20160811153240/http://www.encysol.pl/wiki/Henryk_Bohdan_Samsonowicz (dostęp: 28.06.2021); Kto jest kim - Okrągly Stót. „Solidarność” - opozycja. Biogramy. Wypowiedzi, red. W. Adamiecki, Warszawa 1989, s. 170; A. Sowa, H. Samsonowicz, Świadek epoki. Wywiad rzeka, Warszawa 2009.

2 Ksiega pamiatkowa ku czci profesora Jana Samsonowicza, red. E. Passendorfer, Warszawa 1962; W.R. Brociek, Prof. Jan Samsonowicz - życie i działalność 1888-1959, Ostrowiec Świętokrzyski 2008; Z.J. Wójcik, Samsonowicz Jan, [w:] Polski Słownik Biograficzny, t. 34, Kraków 1992-1993, s. 436-439.

3 T. Siewierski, Marian Małowist i krąg jego uczniów. Z dziejów historiografii gospodarczej w Polsce, Warszawa 2016, s. 162.

4 https://www.1944.pl/powstancze-biogramy/andrzej-samsonowicz,39279.html (dostęp: 28.06.2021).

5 Lucyna Tych z domu Berman (1930-2019) - reżyserka teatralna i telewizyjna. Córka Jakuba Bermana, jej mężem był historyk Feliks Tych. Por.: L. Tychowa, A. Romanowski, Tak, jestem córka Jakuba Bermana, Kraków 2016. 
Karol Grünberg, Hanna Mańkiewicz ${ }^{6}$, Antoni Mączak, Janusz Tazbir, Stanisław Trawkowski i Benedykt Zientara. Pracę magisterską Samsonowicz napisał pod kierunkiem Mariana Małowista i obronił 6 czerwca 1950 r. Jej temat brzmiał: Struktura społeczno-gospodarcza Gdańska od połowy XIV w., do połowy XV wieku? .

Henryk Samsonowicz był zatrudniony w Instytucie Historycznym UW w Katedrze Historii Powszechnej Średniowiecza od 1950 r., kolejno jako: starszy asystent, adiunkt (1953), docent (1960). Profesorem nadzwyczajnym został w 1971 r., a profesorem zwyczajnym w 1980 r. W latach 1983-2000 Samsonowicz był kierownikiem Zakładu Historii Średniowiecznej. W roku 2000 przeszedł na emeryturę. W latach 2000-2010 wykładał jeszcze w Akademii Humanistycznej im. A. Gieysztora w Pułtusku.

Zmarły niedawno uczony przez wiele lat pełnił różnego rodzaju funkcje organizacyjne na Uniwersytecie Warszawskim. W latach 1967-1969 był prodziekanem, a następnie w latach 1969-1974 dziekanem Wydziału Historycznego UW. W 1975 r. Samsonowicz objął funkcję dyrektora Instytutu Historycznego UW, którą pełnił do 1980 r. W latach 1980-1982 historyk był rektorem UW.

Warszawski badacz pełnił też wiele funkcji w Polskim Towarzystwie Historycznym. Był zastępcą sekretarza generalnego (1956-1960), sekretarzem generalnym (1958-1966), następnie wiceprezesem (1966-1971) i prezesem PTH (19781982). Naukowiec był także wiceprzewodniczącym Komitetu Badań Naukowych w latach 1991-1996. W 1993 r. został członkiem korespondentem Polskiej Akademii Umiejętności, czynnym zaś w 1995 r. W 1994 r. został członkiem korespondentem Polskiej Akademii Nauk, rzeczywistym zaś w 2002 r. Był także przewodniczącym Wydziału I Nauk Społecznych PAN (2001-2006) i szefem Zespołu Kierunków Nauk Humanistycznych Państwowej Komisji Akredytacyjnej.

Podczas pracy na uczelni w okresie 1964-2009 Henryk Samsonowicz prowadził seminarium magisterskie. Od 1969 r. pod jego auspicjami odbywało się także seminarium doktoranckie. Spośród uczniów Henryka Samsonowicza, którzy zrobili pod jego kierunkiem doktorat, należy wymienić takie osoby jak: Agnieszka Bartoszewicz ${ }^{8}$, Wojciech Fałkowski ${ }^{9}$, Ewa Kaczorowska-Bielińska ${ }^{10}$,

6 Hanna Dylągowa z domu Mańkiewicz (1928-2016) - historyk XIX wieku, prof. KUL, szwagierka historyka Jerzego Kłoczowskiego. Zob.: M. Kozłowski, In memoriam - Hanna Dylagowa, „Rocznik Lubelski” 44, 2016, s. 407-411.

7 T. Wituch, B. Stolarczyk, Studenci Instytutu Historycznego Uniwersytetu Warszawskiego 1945-2000, Kraków 2010, s. 125.

8 Warta - społeczeństwo miasta $w$ drugiej połowie XV i na początku XVI w., 1995.

9 Elita władzy w Polsce za panowania Kazimierza Jagiellończyka 1447-1492, 1986.

10 Średniowieczne rzemiosto Starej i Nowej Warszawy do 1525 r., 1977. 
Adam Kasperowicz ${ }^{11}$, Jakub Lorenc ${ }^{12}$, Zbigniew Morawski ${ }^{13}$, Grzegorz Myśliwski $^{14}$, Andrzej Olejarczuk ${ }^{15}$, Jerzy Pysiak ${ }^{16}$ oraz Paweł Żmudzki ${ }^{17}$.

Henryk Samsonowicz był doktorem honoris causa wielu uczelni: Duquesne University w Pittsburgu (1981), Akademii Pedagogicznej im. KEN w Krakowie (1994), Uniwersytetu Mikołaja Kopernika w Toruniu (1998) ${ }^{18}$, Uniwersytetu Marii Curie-Skłodowskiej w Lublinie $(2002)^{19}$, Akademii Świętokrzyskiej w Kielcach (2005), ${ }^{20}$ Uniwersytetu Wrocławskiego (2007), Uniwersytetu Opolskiego $(2008)^{21}$, Uniwersytetu Gdańskiego (2009) ${ }^{22}$, Akademii im. Jana Długosza w Częstochowie (2010) ${ }^{23}$, Uniwersytetu im. Adama Mickiewicza w Poznaniu (2014) ${ }^{24}$ i Uniwersytetu Jagiellońskiego (2015). Warszawski historyk był także honorowym obywatelem: Sandomierza (2004), gminy Długosiodło (2006), Ostrowca Świętokrzyskiego (2008), Pułtuska (2008) i Warszawy (2015).

Historyk został odznaczony: Orderem Orła Białego (2010), Krzyżem Komandorskim z Gwiazdą Orderu Odrodzenia Polski (1998), Medalem Stulecia Odzyskanej Niepodległości (2020). Wcześniej, w okresie PRL otrzymał: Krzyż Kawalerski, Oficerski i Komandorski Orderu Odrodzenia Polski, Złoty Krzyż Zasługi i Medal Komisji Edukacji Narodowej. W 1984 r. przyznano mu francuski Krzyż Oficerski Orderu Narodowego Legii Honorowej.

11 Ziemia wiska w średniowieczu. Struktury przestrzenne, osadnicze i społeczne, 1995.

12 Kontakty społeczno-gospodarcze średnich miast polskich na przełomie średniowiecza i epoki nowożytnej (XV-XVI wiek) na przykładzie Sieradza, Warty i Szadka, 2017.

13 Stosunki gospodarcze i społeczne w ziemi łęczyckiej w końcu XIV i na początku XV wieku, 1984.

14 Przestrzeń i czas na Mazowszu w XII - poł. XVI w., 1996.

15 Produkcja towarowa wsi małopolskiej w XVI w. Próba rekonstrukcji, 1976.

16 Monarchia kapetyńska pomiędzy historia, mitem i sacrum w historiografii czasów Filipa Augusta, 1999.

17 Książę Leszek Czarny. Studium podzielonego Królestwa, 1999.

18 R. Czaja, Doktorat honoris causa Uniwersytetu Mikołaja Kopernika w Toruniu dla Profesora Henryka Samsonowicza, „Zapiski Historyczne” 1999, z. 2, s. 171-172.

19 Henryk Samsonowicz doktor honoris causa Uniwersytetu Marii Curie-Skłodowskiej, red. L. Sobolczyk, Lublin 2002.

20 Doctor honoris causa Akademii Świętokrzyskiej im. Jana Kochanowskiego w Kielcach prof. zw. dr hab. Henryk Samsonowicz, Kielce 2005.

21 A. Szylar, Doktoraty „Honoris Causa” Uniwersytetu Opolskiego dla Honorowych Obywateli Sandomierza, „Zeszyty Sandomierskie” (2009), nr 27, s. 104-105.

22 Nadanie Henrykowi Samsonowiczowi tytulu doktora honoris causa Uniwersytetu Gdańskiego, Gdańsk, dnia 19 listopada 2009 roku, Gdańsk 2009.

23 Doctor Honoris Causa Akademii im. Jana Dlugosza w Częstochowie profesor dr hab. Henryk Samsonowicz, Częstochowa 2010.

24 Henricus Samsonowicz. Doctor honoris causa Universitatis Studiorum Mickiewiczianae Posnaniensis (15.X.2014), red. E. Dobosz, Poznań 2014. 
Bibliografia prac Henryka Samsonowicza jest imponująca ${ }^{25}$. Historyk opublikował ponad 1000 prac naukowych, głównie z zakresu historii Polski okresu średniowiecza, w tym kilkadziesiąt książek. 28 czerwca 1954 r. Samsonowicz otrzymał stopień doktora nauk na podstawie pracy kandydackiej zatytułowanej Rzemiosło wiejskie w Polsce w XIV-XVI w. (Warszawa 1954) przygotowanej pod kierunkiem profesora Mariana Małowista. Jej recenzentami byli: Stanisław Herbst, Aleksander Gieysztor, Stanisław Arnold. Początkowo Samsonowicz zajmował się dziejami handlu bałtyckiego. Efektem tego była popularna książka wydana w serii Światowid - Hanza władczyni mórz (Warszawa 1958). Następnie ukazała się jego praca habilitacyjna Badania nad kapitałem mieszczańskim Gdańska w II połowie XV w. (Warszawa 1960, tłum. niemieckie 1969). Uwieńczeniem wieloletnich badań nad dziejami Hanzy było obszerne studium Późne średniowiecze miast nadbałtyckich. Studia $z$ dziejów Hanzy nad Bałtykiem w XIV-XV w. (Warszawa 1968). W latach siedemdziesiątych XX w. tematyka prac uczonego ewoluowała w kierunku historii społecznej i kultury, czego świadectwem były prace: Życie miasta średniowiecznego (Warszawa 1970) i Złota jesień polskiego średniowiecza (Warszawa 1971). Historyk wraz z Marią Bogucką przygotował syntezę dziejów miast i mieszczaństwa w Polsce Dzieje miast $i$ mieszczaństwa $w$ Polsce przedrozbiorowej (Warszawa 1986). Średniowiecznym miastom poświęcił też kilka innych mniejszych prac, które zostały wydane w dwóch zbiorach: Studia $z$ dziejów miast w średniowieczu (Warszawa 2014) i Szkice o mieście średniowiecznym (Warszawa 2014).

Henryk Samsonowicz miał też wielkie zasługi jako popularyzator wiedzy historycznej. Warto tu wymienić książki: Było czy nie było. Wesoła encyklopedia historyczna (współautor J.S. Kopczewski, Warszawa 1961 ${ }^{26}$ ), Krzyżacy (Warszawa 1988) i Łokietkowe czasy (Warszawa 1989). Warszawski historyk był też autorem wielokrotnie wznawianej syntezy Historia Polski do roku 1795 (Warszawa 1967, wyd. 2 - 1973, wyd. 3 - 1976, wyd. 4 - 1985, wyd. 5 popr. - 1990).

25 A. Derelkowski, J. Borawski, Z. Morawski, Bibliografia prac Henryka Samsonowicza za lata 1952-1990, [w:] Czas, przestrzeń, praca $w$ dawnych miastach. Studia ofiarowane Henrykowi Samsonowiczowi w sześćdziesiąta rocznicę urodzin, red. A. Wyrobisz, M. Tymowski, Warszawa 1991, s. 5-31; P. Węcowski, Bibliografia prac Henryka Samsonowicza za lata 1991-2001, [w:] Monarchia w średniowieczu. Władza nad ludźmi, władza nad terytorium. Studia ofiarowane profesorowi Henrykowi Samsonowiczowi, red. J. Pysiak, A. Pieniądz-Skrzypczak, M.R. Pauk, Warszawa-Kraków 2002, s. 13-41; Uzupetnienia do bibliografii prac Henryka Samsonowicza za lata 1952-1990, [w:] Monarchia w średniowieczu..., s. 41-44; I. Jesionowska, M. Radomski, Bibliografia prac Henryka Samsonowicza za lata 2001-2009, [w:] Świat średniowiecza. Studia ofiarowane profesorowi Henrykowi Samsonowiczowi, red. A. Bartoszewicz, G. Myśliwski, J. Pysiak, P. Żmudzki, Warszawa 2010, s. $7-16$.

26 Wznowienie po latach jako: Zagadki historyczne, Warszawa 1996. 
Książka była przeznaczona jako popularne ujęcie dziejów Polski dla uczniów szkół średnich. Przez lata była lekturą dla uczestników olimpiad historycznych czy kandydatów na studia wyższe ${ }^{27}$. Inną próbą zmierzenia się z syntezą dziejów Polski były tomy Tysiącletnie dzieje (współautor, Wrocław 1997) i Polska. Losy państwa i narodu do 1939 roku (współautor, Warszawa 2003). Pod jego redakcją ukazały się też trzy tomy dotyczące historii powszechnej średniowiecza (Narodziny średniowiecznej Europy, Warszawa 1999; Rozkwit średniowiecznej Europy, Warszawa 2003; Schyłek średniowiecznej Europy, Warszawa 2003).

Ważnym wydarzeniem historiograficznym był też wybór Roczników czyli kronik sławnego Królestwa Polskiego Jana Długosza pod redakcją Henryka Samsonowicza, który ukazał się pt. Polska Jana Długosza (Warszawa 1984). Warto wspomnieć, że edycja i przekład całego dzieła rozpoczęła się w 1961 r., a zakończyła dopiero w 2006 r. Samsonowicz był też autorem biografii pt. Konrad Mazowiecki (1187/88 - 31 VIII 1247) (Kraków 2008).

Ostatnie trzy dekady życia Profesora przyniosły wiele pozycji książkowych o różnej tematyce. Można tu wymienić takie publikacje jak: Dziedzictwo Średniowiecza. Mity i rzeczywistość (Wrocław 1991, wyd. 2 popr. i uzup. 2009); Miejsce Polski w Europie (Warszawa 1995, tłum. niemieckie 1997); O „historii prawdziwej". Mity, legendy i podania jako źródło historyczne (Warszawa 1997); Idea uniwersytetu u schyłku tysiaclecia (współautor, Warszawa 1998); Co by było, gdyby... historie alternatywne, z Henrykiem Samsonowiczem rozmawiają Janusz Osica i Andrzej Sowa (Warszawa 1998); Północ-Południe (Wrocław 1999); Ziemie polskie $w X$ wieku i ich znaczenie $w$ ksztattowaniu się nowej mapy Europy (redakcja, Kraków 2000); Długi wiek X. Z dziejów powstawania Europy (Poznań 2002, tłum. niemieckie 2009); Dzień chrztu i co dalej... (Warszawa 2008); Prawda i fałsz. O polskiej chwale i wstydzie (współautor, Łomża 2010); Nieznane dzieje Polski. W Europie czy na jej skraju? (Warszawa 2012); Polska otwarta czy zamknięta (wybór, red. i wstęp, Łomża 2016); My o sobie. Portret własny mieszkańców ziem polskich u schyłku średniowiecza (Warszawa 2017) ${ }^{28}$. Jak widać, głównym tematem tych prac była próba określenia miejsca Polski w Europie $\mathrm{X}-\mathrm{XV}$ w. w aspekcie politycznym, kulturowym, cywilizacyjnym, społecznym, gospodarczym. Warto wspomnieć, że jedna z ciekawszych publikacji Samsonowicza dotyczyła postrzegania przestrzeni przez ludzi średniowiecza (Studia nad postrzeganiem przestrzeni przez ludzi średniowiecza, Warszawa 2015).

27 Warto dodać, że Samsonowicz był w 1975 r. organizatorem pierwszej olimpiady historycznej.

28 Można byłoby tu jeszcze wymienić wiele innych studiów na łamach polskich i zagranicznych czasopism oraz zamieszczonych w pracach zbiorowych. 
Osobnym aspektem jest działalność polityczna Henryka Samsonowicza. Uczony był członkiem PZPR w latach 1956-1982. Warto przy tym podkreślić, że w marcu 1968 r. Samsonowicz był obrońcą przed komisją dyscyplinarną UW studentów Instytutu Historii UW zagrożonych relegowaniem z uczelni. W 1968 roku jako jedyny członek Wyższej Komisji Dyscyplinarnej przy Ministrze Oświaty i Szkolnictwa Wyższego dla pracowników naukowo-dydaktycznych szkół wyższych głosował przeciwko podtrzymaniu decyzji uczelnianej komisji dyscyplinarnej o zwolnieniu profesora Damazego Tilgnera z UW.

W sierpniu 1980 roku Henryk Samsonowicz podpisał apel 64 naukowców, literatów i publicystów o podjęcie dialogu ze strajkującymi robotnikami. Następnie był zaangażowany w działalność w NSZZ „Solidarność”. W kwietniu 1982 r. został z powodów politycznych usunięty z funkcji rektora Uniwersytetu Warszawskiego. W tym samym roku historyka wykluczono z PZPR ${ }^{29}$. W 1985 r. Samsonowicz był współautorem opracowania Raport. Polska 5 lat po sierpniu wydanego w tzw. drugim obiegu. Wybitny mediewista był także Przewodniczącym Komisji Nauki i Oświaty Komitetu Obywatelskiego przy Lechu Wałęsie (1988-1990). W 1989 r. był uczestnikiem obrad Okrągłego Stołu. Po wyborach do Sejmu kontraktowego został ministrem edukacji narodowej w rządzie Tadeusza Mazowieckiego. Funkcję tę sprawował do 12 stycznia 1991 r.

Zupełnie nieznana jest rola Henryka Samsonowicza w powstaniu tzw. komisji Michnika. Minister edukacji sprawował z urzędu nadzór nad całością archiwów państwowych. Powołanie nieformalnej komisji odbyło się z inicjatywy ministra spraw wewnętrznych Krzysztofa Kozłowskiego na podstawie jego osobistej prośby. Dotyczyła ona tego, by Samsonowicz wystawił cztery zaproszenia dla wskazanych przez Kozłowskiego osób, aby mogły skorzystać z archiwum MSW. Chodziło o stworzenie pozoru, że tymi zaproszeniami minister Samsonowicz z urzędu powołuje komisję uprawnioną do dostępu do ściśle zastrzeżonego archiwum MSW. Samsonowicz nie powołał bowiem komisji oficjalnie, ponieważ wówczas jej skład musiałby zostać skompletowany na podstawie przepisów prawa. Zespół ten pracował od 12 kwietnia do 27 czerwca 1990 r. w archiwach MSW. W jego skład wchodzili: dyrektor Archiwum Akt Nowych Bogdan Kroll, prof. Jerzy Holzer, prof. Andrzej Ajnenkiel i poseł Adam Michnik. Po ujawnieniu w prasie istnienia komisji zaprzestała ona działalności ${ }^{30}$.

29 Warto dodać, że w okresie od 30 stycznia 1982 do 23 września 1989 r. Samsonowicz był rozpracowywany przez Wydział III Komendy Stołecznej MO/SUSW w ramach sprawy operacyjnego sprawdzenia krypt. „Goliat”.

30 https://wiadomosci.onet.pl/kiosk/wildstein-a-komisja-michnika/5yprf (dostęp: 08.09. 2021). 
Henryk Samsonowicz zmarł 28 maja 2021 r. w Warszawie. 10 czerwca tego roku został pochowany w Alei Zasłużonych na Powązkach w Warszawie. Pozycja tego wybitnego historyka-mediewisty w świecie nauki była niezwykle wysoka. Jego śmierć jest bez wątpienia dużym ciosem dla nauki polskiej.

Michał Kozłowski - mgr, historyk, pracownik Wojskowego Biura Historycznego im. K. Sosnkowskiego (Sekcja Badań nad Wojskiem po 1945 r.). Zajmuje się głównie historią historiografii. e-mail: micha.kozlowski@ron.mil.pl 